\title{
Nutrient regulation of gamma-aminobutyric acid release from islet beta cells
}

\author{
A. Smismans, F. Schuit, D. Pipeleers \\ Diabetes Research Center, Vrije Universiteit Brussel, Brussels, Belgium
}

\begin{abstract}
Summary Glutamate decarboxylase (GAD) of pancreatic beta cells seems to be involved in the development of autoimmune reactivities which occur in insulin-dependent diabetes mellitus. Little is known about the regulation and role of the GAD activity in normal beta cells. In the $\beta$ TC6 line, the enzymatic product, gamma-aminobutyric acid (GABA) was reported to be released under glucose stimulation, thus supporting the concept that GABA transmits a suppressive action of glucose-stimulated beta cells on neighbouring alpha cells. In this study GABA was found to be released from normal rat beta cells. Over 24-h culture periods, the released amounts represented a constant fraction ( $25 \%$ per $h$ ) of the cellular GABA content. Cellular GABA content and release were dose-dependently increased by the glutamine concentration in the medium; both values decreased following a sustained $(24 \mathrm{~h})$ glucose activation (culture at 10 or $20 \mathrm{mmol} / \mathrm{l}$ glucose instead of $3 \mathrm{mmol} / \mathrm{l})$. The variations in the medium GABA
\end{abstract}

content did not parallel the changes in insulin release, indicating that both beta-cell secretory products follow different routes of storage and release. We suggest that beta cells can discharge GABA via exocytosis of microvesicles storing GABA as well as via direct transport from the cytoplasmic pool of newly formed product. Variations in GABA production result in parallel changes in extracellular GABA concentration; the high fractional release of GABA makes it also a likely parameter of the cellular GAD activity. Since chronically elevated glucose levels result in a reduced GABA discharge from the beta cells, it is conceivable that the subsequent decrease in GABA-mediated suppression of the alpha cells is responsible for a higher glucagon release, as observed in diabetes. [Diabetologia (1997) 40: 1411-1415]

Keywords Glutamate decarboxylase, gamma-aminobutyric acid, islet, insulin, diabetes mellitus.
The presence of glutamate decarboxylase (GAD) in pancreatic beta cells seems responsible for the development of autoimmune reactivities in insulin-dependent diabetes mellitus [1-4]. It has been suggested

Received: 29 April 1997 and in revised form: 6 August 1997

Corresponding author: Prof. D. Pipeleers, Diabetes Research Center, Vrije Universiteit Brussel, Laarbeeklaan 103, B-1090 Brussels, Belgium

Abbreviations: GABA, gamma-amino-n-butyric acid; BSA, bovine serum albumin; GABAase, an enzyme preparation from Pseudomanas Fluorescence consisting of gamma-aminon-butyric acid-transaminase and succinic semialdehyde dehydrogenase; GAD, glutamate decarboxylase; SLMV, Synapticlike microvesicles. that reduced GAD expression by the beta cells might prevent their immune-mediated destruction [5-7]. Whether the resulting reduction in GAD activity would have any functional consequences for the beta cells, or for any of the other islet cells, is still unknown. In fact, little is known about the role of GAD in the endocrine pancreas. In rat islets, GAD has been localized in the beta cells and in peripheral neurons [8-10]. Its presence is associated with the occurrence of gamma-aminobutyric acid (GABA), its enzymatic product [9-11]. Theoretically, the production of GABA by beta cells could influence their own metabolic activity through catabolism via the Krebs cycle [9, 12, 13]; in addition, GABA release in the extracellular medium might allow beta cells to 
regulate neighbouring cells that express GABA receptors $[14,15]$. There is presently no evidence for the existence of GABA receptors on beta cells. Uptake experiments with ${ }^{3} \mathrm{H}$-GABA have suggested the presence of GABA receptors on rat islet delta cells [15], while electrophysiological studies have raised indirect support for $\mathrm{GABA}_{\mathrm{A}}$ receptors on alpha cells [14]. These sites are thought to exert inhibitory actions on somatostatin and glucagon release $[9$, 14]. They might then transmit a suppressive effect of local neural or endocrine - i. e. beta cell - origin. However it remains unknown whether GABA plays a role in the in vivo regulation of pancreatic hormone release. There is no information on the local GABA concentrations and their variation under physiological or pathological conditions. Furthermore, available data are not necessarily indicative for normal cells. In the $\beta$ TC6 cell line, prolonged elevation of glucose resulted in increased GABA release; this observation was taken as support for the concept that glucose-activated beta cells suppress neighbouring alpha cells through release of more GABA [16]. This study was however conducted in the absence of amino acids, and hence of glutamine, which is considered to be a major precursor of GABA [17]. In the present experiments, we examined the effects of glutamine and of glucose on the GABA content and release in normal rat beta cells. The use of purified beta-cell preparations avoids interference by non-beta cells, which is an advantage in assessing interactions at the level of the beta cells. The choice of this experimental model does not deny possible influences by islet nonbeta cells; the latter are, however, best investigated after information is collected on the conditions which regulate GABA release in beta cells.

\section{Materials and methods}

Isolation and culture of beta cells. Rat islet beta cells were purified as previously described [18]. Briefly, pancreatic islets were isolated from adult male Wistar rats by collagenase digestion and then dissociated in a calcium-free medium containing $\mathrm{DN}$-ase $(5 \mu \mathrm{g} / \mathrm{ml})$ and trypsin $(6 \mu \mathrm{g} / \mathrm{ml})$. The dispersed islet cell preparation was then sorted in a FACStar Plus flow cytometer (Becton Dickinson \& Co., Sunnyvale, Calif., USA). The single beta cells (more than $95 \%$ pure) were reaggregated after sorting during a $2 \mathrm{~h}$ shaking incubation at $37^{\circ} \mathrm{C}$ in Ham's F10 medium (Gibco, Strathclyde, UK) containing $0.25 \mathrm{mmol} / 1$ glutamine supplemented with $10 \mathrm{mmol} / 1$ glucose, $0.5 \%$ charcoal extracted bovine serum albumin (BSA) (Type V, Boehringer Mannheim, Mannheim, Germany), $0.075 \mathrm{~g} / \mathrm{l}$ penicillin and $0.1 \mathrm{~g} / \mathrm{l}$ streptomycin. The aggregates were cultured in suspension (5\% $\mathrm{CO}_{2}$, humidified air) in Lux dishes (Nunc, Rockville, Md., USA ) at a concentration of $1.5 \times 10^{5}$ cells per dish with $3 \mathrm{ml}$ medium. After $16 \mathrm{~h}$ of static culture the cells were washed in basal medium, consisting of glutamine-free Ham's F10 containing $3 \mathrm{mmol} / \mathrm{l}$ glucose, $0.075 \mathrm{~g} / \mathrm{l}$ penicillin, $0.1 \mathrm{~g} / \mathrm{l}$ streptomycin and $0.5 \%$ BSA, and cultured for a further $24 \mathrm{~h}$ in $2 \mathrm{ml}$ basal medium supplemented as indicated in Results. After this second culture period, cells and media were collected for GABA and insulin determinations (see below). The cellular GABA and insulin content were measured in cell extracts after sonication. The GABA and insulin content of the cells and the collected medium are expressed as function of the initial number of cells counted at the start of culture.

GABA and insulin assays. The GABA content of cells and medium was determined via enzymatic cycling for NADPH [19]. Fifty microlitre samples were incubated for $30 \mathrm{~min}, 37^{\circ} \mathrm{C}$ after addition of $80 \mu \mathrm{l} \mathrm{GABA}$ assay reagent $(0.3 \mathrm{~mol} / \mathrm{l}$ Tris- $\mathrm{HCl}$ buffer - pH 8.9, 0.6 U/ml GABAse [Boehringer Mannheim] $5 \mathrm{mmol} / \mathrm{l} \alpha$-ketoglutarate, $0.01 \%$ mercaptoethanol, $0.5 \mathrm{mmol} / \mathrm{l}$ $\mathrm{NADP}^{+}$). At the end of the reaction, $20 \mu \mathrm{l} 1.5 \mathrm{~N}$ sodium hydroxide was added and the incubation was continued for $20 \mathrm{~min}$ at $60^{\circ} \mathrm{C}$ to destroy any excess of $\mathrm{NADP}^{+}$. A $20 \mu \mathrm{l}$ aliquot was mixed with $250-\mu$ l enzyme cycling reagent consisting of $0.2 \mathrm{~mol} / \mathrm{l}$ Tris- $\mathrm{HCl}$ buffer $(\mathrm{pH} 8.0), 5 \mathrm{mmol} / \mathrm{l} \alpha$-ketoglutarate, $1 \mathrm{mmol} / 1$ glucose 6 -phosphate, $25 \mathrm{mmol} / \mathrm{l}$ ammonium acetate, $0.1 \mathrm{mmol} / 1$ ADP, $0.02 \%$ BSA, $3.3 \mathrm{U} / \mathrm{ml}$ glutamate dehydrogenase (Boehringer) and $2.5 \mathrm{U} / \mathrm{ml}$ glucose 6 -phosphate dehydrogenase (Boehringer). This reaction was carried out at $37^{\circ} \mathrm{C}$ for $1 \mathrm{~h}$ and stopped by heating at $100^{\circ} \mathrm{C}$ for $7 \mathrm{~min}$. In the third reaction, 6-phosphogluconate production was determined through the formation of NADPH during its conversion to ribulose-phosphate by 6-phosphogluconate dehydrogenase. Ninety microlitre samples were mixed with $250 \mu \mathrm{l}$ assay reagent containing $0.1 \mathrm{~mol} / \mathrm{l}$ Tris- $\mathrm{HCl}$ (pH 8.0), $1 \mathrm{mmol} / \mathrm{l}$ $\mathrm{NADP}^{+}, 0.4 \mathrm{mmol} / \mathrm{l}$ EDTA, $22 \mathrm{mU} / \mathrm{ml}$ 6-phosphogluconate dehydrogenase (Boehringer) and incubated for $30 \mathrm{~min}$ at $25^{\circ} \mathrm{C}$. The final absorbance was recorded at $340 \mathrm{~nm}$. Standard curves were linear between 25 pmol and 250 pmol. Sensitivity was three fold higher than in HPLC analysis. The variation coefficient for inter- and intra-assay determinations was respectively 6 and $3 \%$.

The insulin radioimmunoassay was performed as previously described [20]

Statistical analysis. Data are presented as means \pm SEM, and groups of data were analysed by ANOVA.

\section{Results}

$G A B A$ release during culture of rat beta cells. At the end of a $24 \mathrm{~h}$ culture period at $10 \mathrm{mmol} / \mathrm{l}$ glucose in the absence of glutamine, the GABA content in the medium $\left(34.4 \pm 2.9 \mathrm{pmol} \cdot 10^{3} \mathrm{cells}^{-1} \cdot 24 \mathrm{~h}^{-1}\right)$ was 4.5 times higher than that in the cells $(7.5 \pm 1.2 \mathrm{pmol} /$ $10^{3}$ cells). Addition of GABA to the culture medium resulted in a quantitative recovery (over $95 \%$ ) after $24 \mathrm{~h}$, both in the absence and presence of cells, indicating that the measured values are not influenced by degradation or uptake processes and can therefore be taken as an expression of release. It has been previously shown that beta cells do not exhibit GABA-uptake from the extracellular medium [21] as is also the case for certain other GABA-producing cells [22]. In contrast to the GABA data, the insulin content in the medium $\left(5.5 \pm 0.7 \mathrm{ng} \cdot 10^{3}\right.$ cells per $24 \mathrm{~h}$ ) was only one third of that in the cells $\left(14.9 \pm 1.1 \mathrm{ng} / 10^{3}\right.$ cells). Consequently, the fractional release of GABA calculated as the ratio of medium GABA content over cellular GABA content - was 




Fig.1. Effect of different glutamine concentrations on GABA and insulin release from reaggregated purified beta cells during $24 \mathrm{~h}$ culture at $3 \mathrm{mmol} / \mathrm{l}$ glucose. Data are shown as means \pm SEM of four independent experiments. Statistical significance of differences with $0 \mathrm{mmol} / \mathrm{l}$ glutamine calculated by ANOVA, $* p<0.05$

12 times higher $(4.6 \pm 0.4)$ than that of insulin $(0.4 \pm 0.6)$.

Effects of glutamine and glucose. When rat beta cells were cultured at $3 \mathrm{mmol} / \mathrm{l}$ glucose, GABA release in the medium dose-dependently increased in the presence of 0.25 and $2 \mathrm{mmol} / \mathrm{l}$ glutamine (Fig. 1). However, no changes in insulin release were observed (Fig. 1). The GABA content of the cells was also higher at 0.25 and $2 \mathrm{mmol} / \mathrm{l}$ glutamine (respectively $11.2 \pm 1.0$ and $14.1 \pm 1.2 \mathrm{pmol} / 10^{3}$ cells vs $7.1 \pm 0.7$ $\mathrm{pmol} / 10^{3}$ cells at $0 \mathrm{mmol} / 1$ glutamine, $\left.p<0.05, n=4\right)$, indicating that total GABA accumulation is elevated by glutamine. An increase of the glucose concentration to 10 and $20 \mathrm{mmol} / \mathrm{l}$, did not result in a higher GABA release in a glutamine-free medium, while it resulted in a higher insulin release (Fig. 2). At $2 \mathrm{mmol} / \mathrm{l}$ glutamine, higher glucose levels (10 and $20 \mathrm{mmol} / \mathrm{l}$ ) inhibited GABA release while stimulating insulin release (Fig. 2). The corresponding cellular GABA content varied in parallel with the medium GABA content, indicating that glutamine-induced GABA accumulation is inhibited by glucose (Table 1). The presence of isobutylmethylxanthine (IBMX) $(50 \mu \mathrm{mol} / \mathrm{l})$ prevented this inhibitory effect of glucose on GABA accumulation (Table 1) and release (Fig. 2) while amplifying its stimulatory effect on insulin release (Fig. 2).

Under all tested in vitro conditions, beta cells released approximately $25 \%$ of their GABA content per hour. Plotting of all collected data on medium and cellular content indicated a strong correlation between both parameters as evaluated by regression analysis $(r=0.9, p<0.01)$ (Fig. 3).

Effects of acetylcholine, clonidine and tumor promoting phorbol ester (TPA). Addition of acetylcholine

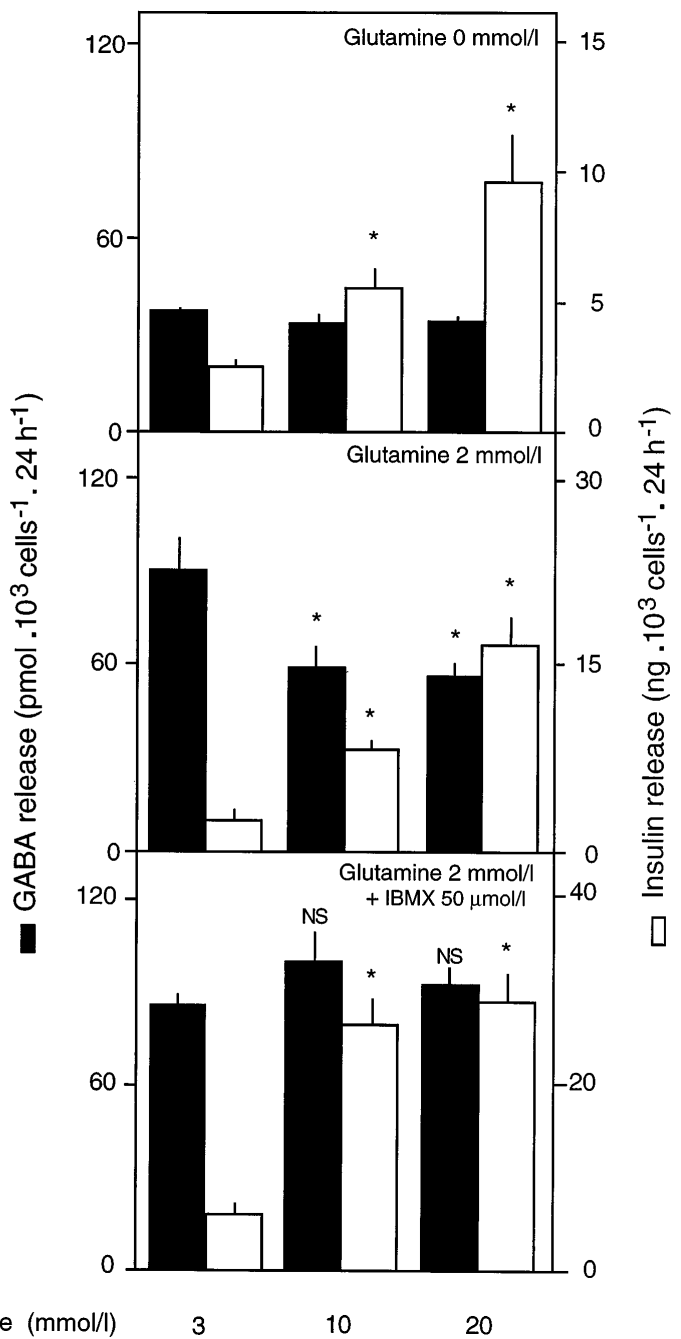

Fig. 2. Effect of glucose concentration on GABA and insulin release from reaggregated purified beta cells during $24 \mathrm{~h}$ culture at $0 \mathrm{mmol} / \mathrm{l}$ or $2 \mathrm{mmol} / \mathrm{l}$ glutamine with or without isobutylmethylxanthine. Data are shown as means \pm SEM of four independent experiments. Statistical significance of differences with $3 \mathrm{mmol} / \mathrm{l}$ glucose calculated by ANOVA, $p<0.05$

$\left(10^{-6} \mathrm{~mol} / \mathrm{l}\right)$ or clonidine $\left(10^{-7} \mathrm{~mol} / \mathrm{l}\right)$ did not influence GABA release during $24 \mathrm{~h}$ culture $\left(51 \pm 6 \mathrm{pmol} / 10^{3}\right.$ control cells vs $57 \pm 8 \mathrm{pmol} / 10^{3}$ cells with acetylcholine and $45 \pm 7 \mathrm{pmol} / 10^{3}$ cells with clonidine, $p>0.05, n=4)$. These agents respectively stimulated and inhibited insulin release under this condition $\left(8 \pm 0.3\right.$ control cells vs $15 \pm 0.4 \mathrm{ng} / 10^{3}$ cells with acetylcholine and $5 \pm 0.4 \mathrm{ng} / 10^{3}$ cells with clonidine, $p<0.05, n=4)$. Neither was a variation in GABA release measured after addition of L-Dopa $\left(10^{-4} \mathrm{~mol} / \mathrm{l}\right)$ or TPA $\left(10^{-8} \mathrm{~mol} / \mathrm{l}\right)$.

\section{Discussion}

This study demonstrates that normal rat beta cells release GABA. The released amounts can vary with the 


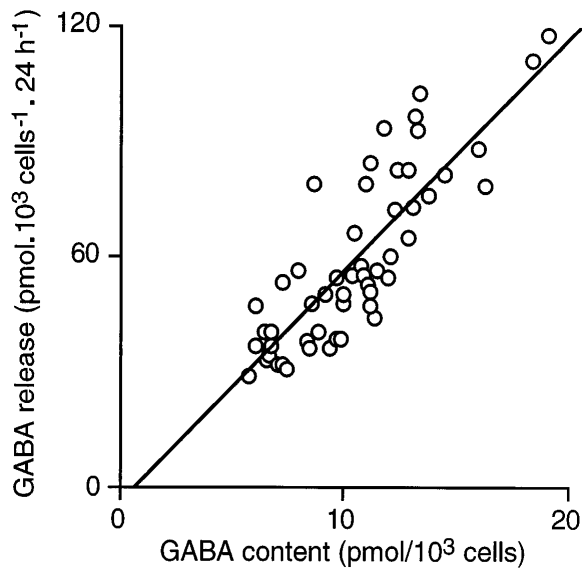

Fig.3. Correlation between GABA release and cellular GABA content following $24 \mathrm{~h}$ culture of rat islet beta cells at varying glutamine or glucose concentrations, with or without $50 \mu \mathrm{mol} / \mathrm{l}$ isobutylmethylxanthine, evaluated by linear regression analysis $(r=0.9, p<0.01)$

Table 1. Effect of glucose on GABA release and cellular GABA content in cultured rat beta cells

\begin{tabular}{llllc}
\hline $\begin{array}{l}\text { Culture condition } \\
(24 \mathrm{~h} \text { at } 2 \mathrm{mmol} / \mathrm{l} \\
\text { glutamine }\end{array}$ & \multicolumn{3}{l}{ GABA content } \\
\cline { 3 - 5 } & Medium & Cells & Total \\
Glucose & IBMX & & $\left(\mathrm{pmol} / 10^{3}\right.$ cells $)$ \\
$3 \mathrm{mmol} / \mathrm{l}$ & - & $91.2 \pm 9.6$ & $14.1 \pm 1.2$ & $105.3 \pm 11.8$ \\
& + & $84.0 \pm 4.8$ & $10.9 \pm 1.1$ & $94.9 \pm 5.9$ \\
$10 \mathrm{mmol} / \mathrm{l}$ & - & $57.6 \pm 7.2^{\mathrm{a}}$ & $10.1 \pm 1.2^{\mathrm{a}}$ & $67.7 \pm 8.4^{\mathrm{a}}$ \\
& + & $98.4 \pm 9.6$ & $14.5 \pm 2.4$ & $112.9 \pm 12.0$ \\
$20 \mathrm{mmol} / \mathrm{l}$ & - & $55.2 \pm 4.8^{\mathrm{b}}$ & $10.1 \pm 1.6^{\mathrm{b}}$ & $65.3 \pm 6.4^{\mathrm{b}}$ \\
& + & $91.2 \pm 4.8$ & $13.7 \pm 0.8$ & $104.9 \pm 5.6$ \\
\hline
\end{tabular}

Data represent means \pm SEM of 4 independent experiments. Statistical significance of differences between ${ }^{\text {a } 3}$ and $10 \mathrm{mmol} / \mathrm{l}$ glucose; between ${ }^{\mathrm{b}} 3$ and $20 \mathrm{mmol} / \mathrm{l}$ was calculated by ANOVA $\left({ }^{\mathrm{a}, \mathrm{b}} p<0.05\right)$

environmental conditions but appear tightly correlated to the cellular GABA content. In all conditions presently tested over a $24 \mathrm{~h}$ culture period, the cells released 5 times their GABA content, indicating that the rate of GABA synthesis in the cells exerts a major influence on the rate of GABA release. However, the release of insulin corresponded to only a fraction of the cellular store. It is therefore suggested that the release of GABA is an index of the cellular GABA production. GABA release by beta cells was dose-dependently increased by glutamine. Addition of glutamine is expected to provide amino acids for protein synthesis and substrates for the glutamate dehydrogenase and decarboxylase reactions. GAD activity results in formation of GABA which can be transaminated in the mitochondria [9] or transported into synaptic-like microvesicles (SLMV) [10]. The release of GABA in the extracellular medium is thought to occur by exocytosis of the SLMV [10] but is also conceivable from the cytoplasm through GABA-transporters in the plasma membrane. The latter mechanism may lead to a higher GABA content in the medium when GABA production is increased by glutamine and the excess of cytoplasmic GABA is not (completely) catalysed in the mitochondria or stored in the SLMV.

Cellular accumulation and release of GABA was higher during culture at $3 \mathrm{mmol} / 1$ glucose - when the beta cell population was not in a glucose-activated state - than during culture at 10 and $20 \mathrm{mmol} / \mathrm{l}$ glucose - when virtually all cells exhibited a glucose-activated state [20]. The sustained glucose activation may have reduced the cellular GABA pool via two mechanisms, namely an increased amino acid incorporation in newly synthesized proteins and an increased oxidative degradation, thus leading to a lower discharge of GABA in the extracellular medium. If locally released GABA indeed exerts a tonic suppression of glucagon release $[14,16]$, these data would then indicate that chronically elevated glucose concentrations result in elevated glucagon levels because the beta cells release less GABA under this condition. For a comparable reason, a massive reduction in beta-cell number could be held responsible for an increase in the glucagon release rates. The higher glucagon levels which have been observed in diabetic patients - both insulin-dependent and non-insulin-dependent $[23,24]-$ might thus be the consequence of a diminished GABA release from the beta cells. Failure of glucose to suppress glucagon release in diabetic subjects can also be explained within this concept [23]. Additional studies are of course needed to further explore this possibility.

Our observations are consistent with data of Gylfe and Hellman [25], indicating a reduced GABA accumulation in glucose-stimulated islets from ob/ob mice [25]; the latter study however did not mention whether this reduction was also correlated with a decreased GABA release. On the other hand, high glucose concentrations increased GABA release from a $\beta$ TC6 cell line [16]; it is not clear whether this observation is really discrepant, since these cells lack the characteristic glucose-responsiveness of specific functions such as insulin release.

Our study clearly indicated a dissociation between insulin release and GABA release. Changes in hormone secretion were not associated with parallel variations in GABA release suggesting that the discharge of these two beta cell products is subject to different regulatory mechanisms and follows different subcellular routes. These data do not support the view that GABA is co-released with insulin. They are consistent with previous findings that the secretory vesicles are not the main site for GABA storage in the beta cells [9]. Most cellular GABA is stored in microvesicles which resemble the SLMV in neurons [10]. By measuring the GABA accumulation in the 
culture medium over 24-h periods, we probably fail to detect rapid variations in microvesicle-exocytosis as occurring in neurons exposed to muscarinic or adrenergic stimuli, or subject to changes in intracellular calcium [26]. This may certainly explain the lack of any regulatory effect by neurohormonal agents which induce membrane fusion in islet beta cells; it also underlines the need for another model if microvesicle release is to be studied. On the other hand, the presently used model allowed us to demonstrate the influence of a sustained metabolic state on the release of GABA. Nutrients such as glutamine and glucose were found to exert major effects on the production of GABA, and hence on the cytoplasmic GABA pool. The presence of GABA transporters in the mitochondrial, microvesicular and plasma membrane is expected to keep cytoplasmic GABA concentrations low. An increased discharge in the extracellular medium may thus be an adequate index of the rate of GABA formation. This route of GABA release by the beta cells is still hypothetical, but deserves further investigation in view of its potential regulating function on neighbouring cells.

Acknowledgements. Part of this work was presented at the 32th Congress of the European Association for the Study of Diabetes, Vienna, 1996. This study was supported by grants from the Belgian Ministry of Science Policy (92/97-12) and from the Belgian National Fund for Scientific Research (3.0057-94). Annick Smismans is a research fellow of the Belgian National Fund for Scientific Research.

\section{References}

1. Baekkeskov S, Aanstoot H-J, Christgau S et al. (1990) Identification of the $64 \mathrm{~K}$ autoantigen in insulin-dependent diabetes as the GABA-synthesizing enzyme glutamic acid decarboxylase. Nature 347: 151-156

2. Atkinson M, Kaufman D, Campbell L et al. (1992) Response of peripheral-blood mononuclear cells to glutamate decarboxylase in insulin-dependent diabetes. The Lancet 339: 458-459

3. Kaufman D, Clare-Salzler M, Tian J, Forsthuber T, Ting G, Robinson P (1993) Spontaneous loss of T-cell tolerance to glutamic acid decarboxylase in murine insulin-dependent diabetes. Nature 366: 69-72

4. Tisch R, Yang X, Singer S, Liblau R, Fugger L, Mc Devitt H (1993) Immune response to glutamic acid decarboxylase correlates with insulitis in non-obese diabetic mice. Nature 366: $72-75$

5. Atkinson M, Mac Laren N, Luchetta R (1990) Insulitis and diabetes in NOD mice reduced by prophylactic insulin therapy. Diabetes 39: 933-937

6. Keller R, Eisenbarth G, Jackson R (1993) Insulin prophylaxis in individuals at high risk in type 1 diabetes. Lancet 341: 927-928

7. Schmidli R, Faulkner-Jones B, Harrison L, James R, De Aizpurua H (1996) Cytokine regulation of glutamate decarboxylase biosynthesis in isolated rat islets of Langerhans. Bioch J 317: 713-719
8. Vincent S, Hokfelt T, Wu J, Elde R, Morgan L, Kimmel J (1983) Immunohistochemical studies of the GABA system in the pancreas. Neuroendocrinology 36: 197-204

9. Sorenson R, Garry D, Brelje C (1991) Structural and functional considerations of GABA in islets of Langerhans. Diabetes 40: 1365-1374

10. Reetz A, Solimena M, Matteoli M, Folli F, Takel K, De Camilli P (1991) GABA and pancreatic beta cells: colocalization of glutamic acid decarboxylase (GAD) and GABA with synaptic like microvesicles suggests their role in GABA storage and secretion. EMBO J 10: 1275-1284

11. Gilon P, Campistron G, Geffard M, Remacle C (1988) Immunocytochemical localisation of GABA in endocrine cells of the rat entero-pancreatic system. Biol Cell 62: 265273

12. Michalik M, Erecinska M (1992) GABA in pancreatic islets: metabolism and function. Bioch Pharmacology 44: 1-9

13. Michalik M, Nelson J, Erecinska M (1993) GABA production in rat islets of Langerhans. Diabetes 42: 1506-1507

14. Rorsman P, Berggren P-O, Bokvist K, Ericson H, Mohler H, Ostenson C-G, Smith P (1989) Glucose inhibition of glucagon secretion involves activtion of $\mathrm{GABA}_{\mathrm{A}}$-receptor chloride channels. Nature 341: 233-236

15. Gilon P, Remacle C (1989) High-affinity GABA uptake in a subpopulation of somatostatin cells in rat pancreas. J Histochem Cytochem 37: 1133-1139

16. Gaskins R, Baldeon M, Selassie L, Beverly L (1996) Glucose modulates $\gamma$-aminobutyric acid release from the pancreatic $\beta$ TC6 cell line. J Biol Chem 270: 30286-30289

17. Malaisse W, Sener A, Carpinelli A et al. (1980) The stimulus-secretion coupling of glucose-induced insulin release. Mol Cell Endocrinol 20: 171-189

18. Pipeleers D, In't Veld P, Van De Winkel M, Maes E, Schuit F, Gepts W (1985) A new in vitro model for the study of pancreatic A and B cells. Endocrinology 117: 806-816

19. Okada Y, Taniguch H, Shimada C (1976) High concentration of GABA and high glutamate decarboxylase activity in rat pancreatic islets and human insulinoma. Science 194: 620-622

20. Ling Z, Kiekens R, Mahler Tet al. (1996) Effects of chronically elevated glucose levels on the functional properties of rat pancreatic beta cells. Diabetes 45: 1774-1782

21. Gilon P, Remacle C (1989) High affinity GABA uptake in a subpopulation of somatostatin cells in rat pancreas. J Histochem Cytochem 57: 1133-1139

22. Reisert I, Wohrle M, Pilgrim Ch (1985) Quantitative assessment of GABA-uptake sites in the neural lobe by electron-microscopic autoradiography. Cell Tissue Res 241: $581-584$

23. Unger R, Aguilae-Parada E, Muller W, Eisentraut A (1970) Studies of pancreatic alpha cell function in normal and diabetic subjects. J Clin Invest 49: 837-848

24. Reaven G, Chen, Y-D, Golay A, Swislocki A, Jaspan J (1987) Documentation of hyperglucagonemia throughout the day in nonobese and obese patients with non-insulindependent diabetes mellitus. J Clin Endocrinol Meth 64: 106-111

25. Gylfe E, Hellman B (1973) Role of glucose as a regulator and precursor of amino acids in the pancreatic beta cells. Endocrinology 94: 1150-1156

26. Szerb JC (1983) Mechanisms of GABA release. In: Liss AR (ed) Glutamine, glutamate and GABA in the CNS. Alan R. Liss, New York, pp 457-472 